\title{
DISSEMINE INTRAVASCULAR COAGULATION MAY BE THE PRESENTING FEATURE FOR CHRONIC MYELOMONOCYTIC LEUKEMIA
}

\author{
YAYGIN DAMAR IÇi PIHTILAŞMA ILE GELEN KRONIK MYELOMONOSITIK LÖSEMI
}

\author{
Itır ŞiRINOĞLU DEMIRIZ1 (D, A. Gülsan TÜRKÖZ SUCAK² (D) \\ ${ }^{1}$ Health Sciences University, Bakirkoy Dr Sadi Konuk Training and Research Hospital, Hematology, Istanbul, Turkey \\ ²Bahcelievler Medical Park Hospital, Hematology, Stem Cell Transplantation Clinic, Istanbul, Turkey
}

ORCID IDs of the authors: I.Ş.D. 0000-0001-7931-7104; A.G.T.S. 0000-0002-7707-0029

Cite this article as: Sirinoglu Demiriz I, Sucak Turkoz G. Dissemine intravascular coagulation may be the presenting feature for chronic myelomonocytic leukemia. J Ist Faculty Med 2020;83(4):307-8. doi: 10.26650/IUITFD.2019.0052

Chronic myelomonocytic leukemia (CMML) is a malignant myeloid stem cell disease accompanied by dysplasia in the context of myeloproliferative disease. Peripheral cytopenias (mainly anemia and thrombocytopenia) and hepatosplenomegaly are common findings. Dramatic leukocytosis can also be seen without transformation to acute myeloid leukemia (AML). In some cases, this is associated with leukostasis and end organ damage. Splenomegaly is present in up to $25 \%$ of patients and is often accompanied by hepatomegaly, lymphadenopathy, or nodular cutaneous leukemic infiltrates. The acquired cogulation defect may be due to factor $X$ binding to atypical monocytes, resulting in acquired factor $X$ deficiency.

We would like to highlight the challenging diagnosis and treatment of CMML.

Cases of CMML have a persistent peripheral blood monocyte count $>1000 /$ microL $(>10 \%$ ). Despite a relative increase in monocytes, the total white blood cell count may not be increased. Myeloid dysplasia may be seen in all myeloid cells, and unique abnormal mononuclear cells exhibiting features of both myelocytes and monocytes, termed "paramyeloid cells," are often detected (1).

The World Health Organization (WHO) criteria for the diagnosis of CMML was revised in 2016 as shown in Table 1 (2).
Table 1: WHO criteria for diagnosis of CMML.

Persistent PB monocytosis $>1 \times 10$ e9/L, with monocytes accounting for $\geq 10 \%$ of the white blood cell (WBC) count;

Not meeting $\mathrm{WHO}$ criteria for BCR-ABL1 CML, PMF, $\mathrm{PV}$, or ET;

No evidence of PDGFRA, PDGFRB, or FGFR1 rearrangement or PCM1-JAK2 (should be specifically excluded in cases with eosinophilia);

$<20 \%$ blasts in the blood and BM;

Dysplasia in 1 or more myeloid lineages. If myelodysplasia is absent or minimal, the diagnosis of $\mathrm{CMML}$ may still be made if the other requirements are met and;

An acquired clonal cytogenetic or molecular genetic abnormality is present in hematopoietic cells or the monocytosis (as previously defined) has persisted for at least 3 months and; all other causes of monocytosis have been excluded

CMML is also stratified into different forms according to WBC count, peripheral and bone marrow blast, and promonocyte counts as summarized in Table 2.

Corresponding author/liletişim kurulacak yazar: dritir@hotmail.com

Submitted/Başvuru: 24.07.2019 • Revision Requested/Revizyon Talebi: 12.05.2020 •

Last Revision Received/Son Revizyon: 15.05.2020 • Accepted/Kabul: 02.06.2020 • Published Online/Online Yayın: 19.10.2020

(C)Telif Hakkı $2020 \mathrm{~J}$ Ist Faculty Med - Makale metnine jmed.istanbul.edu.tr web sayfasından ulaşılabilir.

(C) Copyright 2020 by J Ist Faculty Med - Available online at jmed.istanbul.edu.tr 
Table 2: Subgroups of CMML.

\begin{tabular}{|c|c|}
\hline WBC count & $\begin{array}{l}\text { The percentage of blasts } \\
\text { plus promonocytes in the } \\
\text { PB and BM }\end{array}$ \\
\hline $\begin{array}{l}\text { Myelodysplastic, with } \\
\text { WBC count }<13 \times 10 \mathrm{e} 9 / \mathrm{L}\end{array}$ & $\begin{array}{l}\text { CMML-0, (with }<2 \% \text { blasts } \\
\text { in PB and }<5 \% \text { blasts in } \\
\text { BM) }\end{array}$ \\
\hline \multirow[t]{2}{*}{$\begin{array}{l}\text { Proliferative, with WBC } \\
\text { count }>13 \times 10 \mathrm{e} 9 / \mathrm{L}\end{array}$} & $\begin{array}{l}\text { CMML-1 (with } 2-4 \% \text { blasts } \\
\text { in PB and/or } 5-9 \% \text { blasts } \\
\text { in BM); }\end{array}$ \\
\hline & $\begin{array}{l}\text { CMML-2 (with } 5-19 \% \\
\text { blasts in PB, 10-19\% in } \\
\text { BM, and/or when any Auer } \\
\text { rods are present) }\end{array}$ \\
\hline
\end{tabular}

The diagnosis in most cases is usually based upon peripheral blood and bone marrow abnormalities with clinical non-specific features. However bleeding or coagulopathy is extremely rare in the diagnostic period. To date, there have been only a few cases of bleeding diathesis in CMML patients and these cases were under treatment for CMML. Rare cases may be referred to us for DIC and later diagnosed for CMML.

Monocytes express a small amount of procoagulant activity (PCA). However, they can be stimulated to produce tissue factor and other direct factor $\mathrm{X}$ activators. This activation can be triggered by $T$ lymphocytes, various antigens, cytokines, some lipoproteins, immune complexes, endotoxins (3-5). Monocytes may also be activated by tumor-specific antigens and immune complexes or other cytokines containing them. For example, in lung cancer, pulmonary alveolar macrophages adjacent to a tumor increased tissue factor activity in vitro compared to cells from normal controls or macrophages from the contralateral side of the tumor (6). In CMML patients, similar malignancies monocytes may provocate hypercoagulation and procoagulation.

Due to the heterogeneity of the disease, the clinical course and outcomes of patients with CMML are variable. Previous reports have demonstrated that a high proportion of BM blasts, elevated lactate dehydrogenase, male sex and a low $\mathrm{Hb}$ level were independent prognostic factors. Most recently, cytogenetic status and specific gene mutations have been identified as important prognostic factors. The general prognosis of patients with CMML is poor, with an expected median survival of approximately 30 months. Patients with low risk disease by both the MDACC and Mayo scoring systems can delay transplant until the disease has progressed.

For those who are not candidates for allogeneic HCT and who decide not to participate in a clinical trial, we sug- gest symptom-directed therapy with either cytoreductive therapy (eg, hydroxyurea) or hypomethylating agents (eg, azacitidine, decitabine). Cytoreductive therapy is usually preferred for patients with dramatic proliferative symptoms, while hypomethylating agents are preferred for patients with cytopenias and those with myeloproliferative symptoms in whom hydroxyurea is ineffective (7-10).

We should be alert for elderly patients presenting with DIC regarding chronic myeloid neoplasias. Of particular concern is that CMML may imitate more frequent hypercoagulative diseases such as acute promyelocytic leukemia. However, it would be helpful to simply recall the possibility and analyse the peripheral smear for differential diagnosis in detail. Remembering and diagnosing CMML in this group of patients may lead to a remission status after hypometillating agent protocol.

\section{REFERENCES}

1. Bernat AL, Priola SM, Elsawy A, et al. Chronic subdural collection overlying an intra-axial hemorrhagic lesion in chronic myelomonocytic leukemia: special report and review of the literature. Expert Rev Neurother 2018;18(5):371-7. [CrossRef]

2. Arber DA, Orazi A, Hasserjian R, et al. The 2016 revision to the World Health Organization classification of myeloid neoplasms and acute leukemia. Blood 2016;127(20):2391405. [CrossRef]

3. Altieri DC, Edgington TS. The saturable high affinity association of factor $X$ to ADP-stimulated monocytes defines a novel function of the Mac-1 receptor. J Biol Chem 1988;263(15):7007-15.

4. Edwards RL, Rickles FR, Bobrove AM. Mononuclear cell tissue factor: cell of origin and requirements for activation. Blood 1979;54(2):359-70. [CrossRef]

5. Gregory SA, Kornbluth RS, Helin H, et al. Monocyte procoagulant inducing factor: a lymphokine involved in the $\mathrm{T}$ cell-instructed monocyte procoagulant response to antigen. J Immunol 1986;137(10):3231-9.

6. Edwards RL, Rickles FR, Cronlund M. Abnormalities of blood coagulation in patients with cancer. Mononuclear cell tissue factor generation. J Lab Clin Med 1981;98(6):917-28.

7. Kantarjian H, Issa JP, Rosenfeld CS, etal. Decitabine improves patient outcomes in myelodysplastic syndromes: results of a phase III randomized study. Cancer 2006;106(8):1794-803. [CrossRef]

8. Kantarjian H, Oki Y, Garcia-Manero G, et al. Results of a randomized study of 3 schedules of low-dose decitabine in higher-risk myelodysplastic syndrome and chronic myelomonocytic leukemia. Blood 2007;109(1):52-7. [CrossRef]

9. Kantarjian HM, O'Brien S, Shan J, et al. Update of the decitabine experience in higher risk myelodysplastic syndrome and analysis of prognostic factors associated with outcome. Cancer 2007;109(2):265-73. [CrossRef]

10. Santini V, Allione B, Zini G, et al. A phase II, multicentre trial of decitabine in higher-risk chronic myelomonocytic leukemia. Leukemia 2018;32(2):413-8. [CrossRef] 